\title{
Modeling the use of sulfate additives for potassium chloride destruction in biomass
} combustion

Wu, Hao; Grell, Morten Nedergaard; Jespersen, Jacob Boll; Aho, Martti; Jappe Frandsen, Flemming; Glarborg, Peter

\section{Published in:}

Proceedings of the European Biomass Conference and Exhibition

Publication date:

2013

Link back to DTU Orbit

Citation (APA):

Wu, H., Grell, M. N., Jespersen, J. B., Aho, M., Jappe Frandsen, F., \& Glarborg, P. (2013). Modeling the use of sulfate additives for potassium chloride destruction in biomass combustion. In Proceedings of the European Biomass Conference and Exhibition

\section{General rights}

Copyright and moral rights for the publications made accessible in the public portal are retained by the authors and/or other copyright owners and it is a condition of accessing publications that users recognise and abide by the legal requirements associated with these rights.

- Users may download and print one copy of any publication from the public portal for the purpose of private study or research.

- You may not further distribute the material or use it for any profit-making activity or commercial gain

- You may freely distribute the URL identifying the publication in the public portal 


\title{
MODELING THE USE OF SULFATE ADDITIVES FOR POTASSIUM CHLORIDE DESTRUCTION IN BIOMASS COMBUSTION
}

Hao Wu ${ }^{*}, 1$, Morten Nedergaard ${ }^{1}$, Jacob Boll Jespersen ${ }^{1}$, Martti Aho $^{2}$, Flemming Jappe Frandsen ${ }^{1}$, Peter Glarborg ${ }^{1}$

${ }^{1}$ Department of Chemical and Biochemical Engineering, Technical University of Denmark, Søltofts Plads, Building 229, DK-2800 Kgs. Lyngby, Denmark

${ }^{2}$ VTT Technical Research Centre of Finland, P.O. Box 1603, FI-40101, Jyväskylä, Finland

* Corresponding Author. Phone:+45 4525 2927, Fax:+ 454588 2258, Email:haw@kt.dtu.dk

\begin{abstract}
Potassium chloride, $\mathrm{KCl}$, formed from biomass combustion may lead to ash deposition and corrosion problems in boilers. Sulfates are effective additives for converting $\mathrm{KCl}$ to the less harmful $\mathrm{K}_{2} \mathrm{SO}_{4}$. In the present study, the decomposition of ammonium sulfate, aluminum sulfate and ferric sulfate was studied respectively in a fastheating rate thermogravimetric analyzer (TGA) for deriving a kinetic model. The yields of $\mathrm{SO}_{2}$ and $\mathrm{SO}_{3}$ from the decomposition were studied in a tube reactor, revealing that the ratio of the $\mathrm{SO}_{3} / \mathrm{SO}_{2}$ released varied for different sulfate and for ammonium sulfate the ratio was affected by the decomposition temperature. Based on the experimental data, a model was proposed to simulate the sulfation of $\mathrm{KCl}$ by different sulfate addition, and the simulation results were compared with pilot-scale experiments conducted in a bubbling fluidized bed reactor. The simulation results of ammonium sulfate addition and ferric sulfation addition compared favorably with the experimental results. However, the model for aluminum sulfate addition under-predicted significantly the high sulfation degree of $\mathrm{KCl}$ observed in the experiments, possibly because of an under-estimation of the decomposition rate of aluminum. Under the boiler conditions of the present work, the simulation results suggested that the desirable temperature for the ferric sulfate injection was around $950-900^{\circ} \mathrm{C}$, whereas for ammonium sulfate the preferable injection temperature was below $800^{\circ} \mathrm{C}$.
\end{abstract}

Keywords: additives, alkali, biomass, combustion, modeling, ashes

\section{INTRODUCTION}

One of the major technical challenges associated with the use of biomass through combustion technologies is that biomass combustion may result in a considerable amount of alkali chlorides in the flue gas and subsequently lead to severe deposition and corrosion problems in the boiler [1-6]. In order to mitigate the alkali chloride-induced problems, a feasible method is to use additives to convert the alkali chlorides to the less harmful species [7]. Sulfates, including ammonium sulfate, aluminum sulfate and ferric sulfate, have been proven to be very effective in converting the alkali chlorides to the less harmful alkali sulfates [8-10]. The high effectiveness of the sulfate additives are mainly related to the $\mathrm{SO}_{3}$ released during their thermal decomposition, which reacts with alkali chlorides efficiently $[11,12]$. However, despite the presence of extensive experimental investigations on the use of sulfate additives under different boiler conditions [8-10], fundamental studies on the decomposition rate and products of sulfate additives are scare. In relation to this, no modeling work has been carried out to describe the sulfation of alkali chlorides by sulfate addition during biomass combustion. The lack of such knowledge generally limits the optimal use of the sulfate additives.

The objectives of this study were to understand the decomposition behavior of ammonium sulfate, aluminum sulfate and ferric sulfate under boiler conditions, and to develop a model to describe the sulfation of $\mathrm{KCl}$ by sulfate addition during biomass combustion. The decomposition of the sulfates was studied respectively in a fast-heating rate thermogravimetric analyzer (TGA) and a tube reactor. The model developed in this work involved a description of sulfate decomposition, a detailed gas-phase kinetic model for sulfation of potassium chloride based on [12], and a simplified model for homogeneous and heterogeneous nucleation of potassium sulfate [13]. The simulation results of sulfate addition were compared with the experimental results from biomass combustion on a pilot-scale bubbling fluidized bed reactor where ammonium sulfate, aluminum sulfate and ferric sulfate was injected respectively to the freeboard of the reactor. Besides, the effectiveness of different sulfate was compared through simulation.

\section{EXPERIMENTAL}

\subsection{Fast heating rate TGA}

Thermal decomposition of ammonium sulfate, aluminum sulfate and ferric sulfate was studied respectively in a fast heating rate Netzsch STA 449 F1 Jupiter thermogravimetric analyzer (TGA). The experiments were carried out under $\mathrm{N}_{2}$ atmosphere, using pure and dehydrated sulfates. During the experiments, the sulfate was heated at a rate of $500^{\circ} \mathrm{C} / \mathrm{min}$ to an end temperature, and then kept isothermally. The mass loss during the isothermal period was recorded and used to derive the kinetic parameters of sulfate thermal decomposition. For the different sulfate, the end temperatures applied in the experiments differed. For the experiments of ammonium sulfate, the end temperatures were chosen to be in a range of $200-350^{\circ} \mathrm{C}$. For the ferric sulfate experiments, the end temperatures varied from $600^{\circ} \mathrm{C}$ to $800^{\circ} \mathrm{C}$. For the aluminum sulfate experiments, the range of the end temperatures was $700-800^{\circ} \mathrm{C}$.

\subsection{Laboratory-scale tube reactor}

In order to study the yields of $\mathrm{SO}_{2}$ and $\mathrm{SO}_{3}$ from the thermal decomposition of ammonium sulfate, aluminum sulfate and ferric sulfate, experiments were conducted in a laboratory-scale tube reactor. The principles of the reactor and the experiments have been described in detail in our early work [14,15]. In the reactor, the decomposition of sulfate was carried out under welldefined temperature and flow conditions $\left(5 \mathrm{Nl} / \operatorname{min~} \mathrm{N}_{2}\right)$, and the $\mathrm{SO}_{2}$ released were analyzed continuously by an IR-based gas analyzer. Based on the analyzed $\mathrm{SO}_{2}$ 
concentrations over time, a fractional conversion of the sulfur in ferric sulfate to $\mathrm{SO}_{2}$ at the given temperature condition was calculated. The remaining sulfur in ferric sulfate is assumed to be released as $\mathrm{SO}_{3}$. The temperature range studied was $500-1000^{\circ} \mathrm{C}$, where the conversion of $\mathrm{SO}_{3}$ to $\mathrm{SO}_{2}$ is expected to be negligible.

\subsection{Bubbling fluidized bed pilot reactor}

Pilot-scale experiments were conducted in the $20 \mathrm{~kW}$ bubbling fluidized bed (BFB) reactor at the VTT Technical Research Centre of Finland. The fuel used in the experiments was a mixture of $60 \%$ (energy basis) bark and $40 \%$ (energy basis) refuse derived fuel (RDF) comprised mainly of packaging waste from households and industry. The properties of the fuel mixture are given in Table I. The additives used in the experiments were ammonium sulfate, aluminum sulfate, and ferric sulfate aqueous solutions.

Table I: Properties of the fuel mixture of $60 \%$ (energy basis) bark and $40 \%$ RDF.

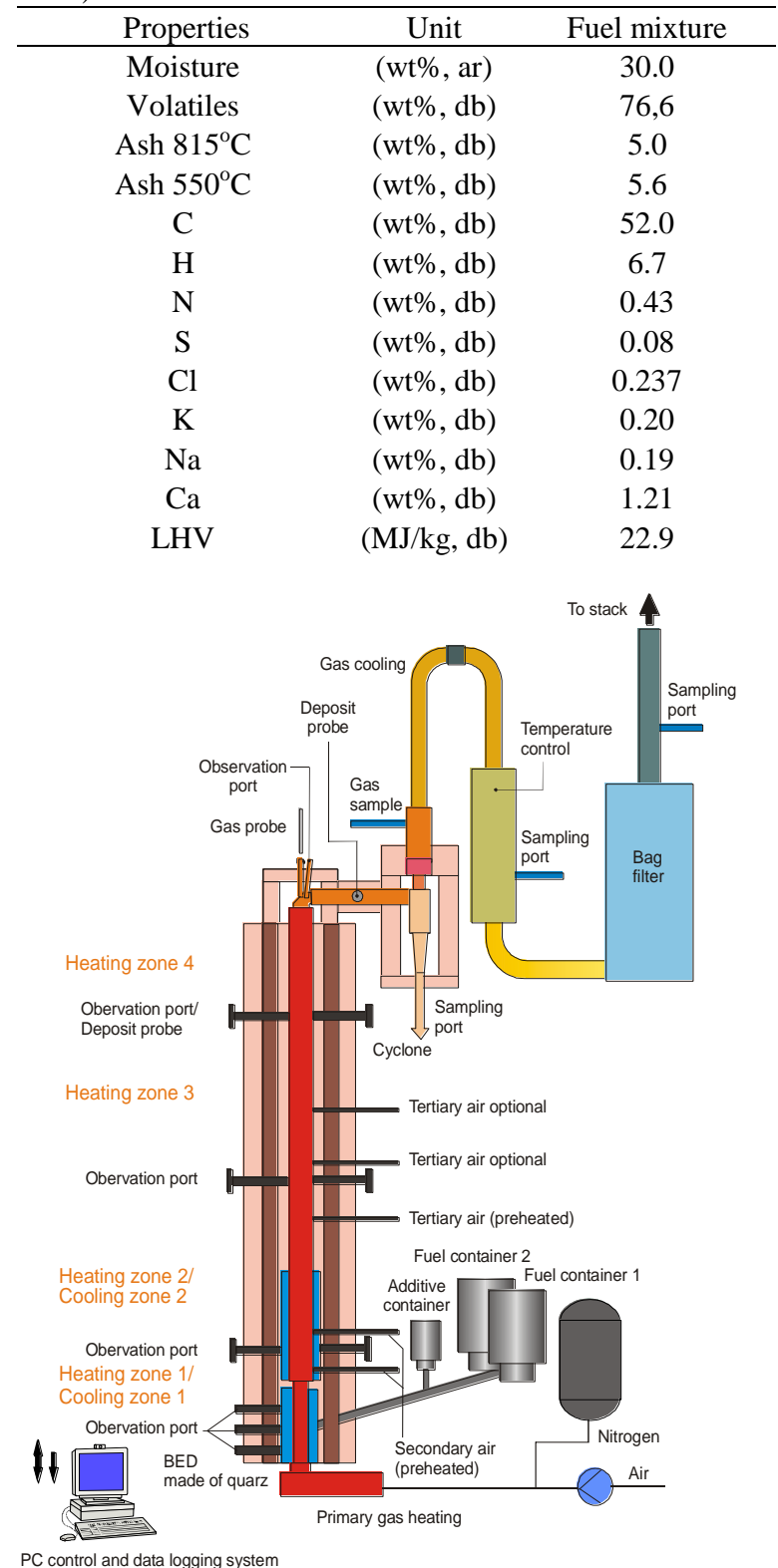

Figure 1: Schematic diagram of the bubbling fluidized bed reactor [9].
A schematic diagram of the BFB reactor is shown in Figure 1. During the experiments, the fuel was fed into the bed with screw-type feeder. The ratio between the primary (fluidizing), second and tertiary air was 50:30:20. The fuel feeding rate was kept at $2.48 \mathrm{~kg} / \mathrm{h}$ (dry basis), and the total air feeding rate was $278 \mathrm{Nl} / \mathrm{min}$. The measured (by thermocouples) temperature distribution as a function of the residence time in the reactor is shown in Figure 2. It can be seen that the freeboard temperature varied, with the highest temperatures measured close to the secondary and tertiary air inlets.

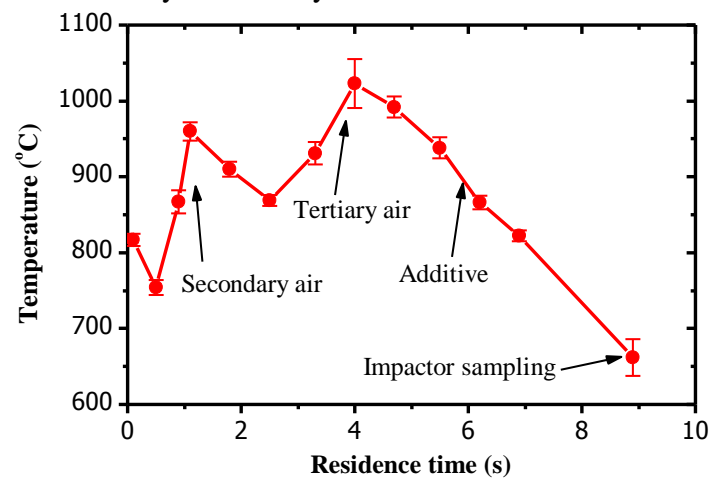

Figure 2: Temperature distribution versus gas residence time in the BFB reactor.

The sulfate additive was sprayed co-currently to the upper part of the freeboard through a nozzle. The residence time corresponding to the additive injection position was $5.8 \mathrm{~s}$, as illustrated in Figure 2. The mean droplet size of the spray was about $10 \mu \mathrm{m}$. The amount of the additive injected was determined based on the fuel $\mathrm{Cl}$ content and feeding rate. The molar ratio of $\mathrm{S}_{\text {additive }} / \mathrm{Cl}_{\text {fuel }}$ was chosen to be 0.225 and 0.75 respectively for the different sulfate.

The aerosols generated in the reactor were collected by a low pressure impactor at flue gas temperatures of about $650^{\circ} \mathrm{C}$. The compositions of the aerosols $(<4 \mu \mathrm{m})$ were analyzed by ion chromatography (IC) for the $\mathrm{Cl}$ and $\mathrm{S}$ content and by flame atomic absorption spectroscopy (FAAS) for the alkali content.

\section{MODEL DEVELOPMENT AND SIMULATION}

\subsection{Deposition of sulfate}

The decomposition of sulfate is assumed to be kinetically controlled and follow the volumetric reaction model:

$\frac{d W}{d t}=-k W$

where $W$ is the relative mass of the anhydrous ferric sulfate defined as:

$W=\frac{m-m_{\infty}}{m_{0}-m_{\infty}}$

where $m_{0}(\mathrm{~g})$ is the mass of the anhydrous sulfate before decomposition, $m_{\infty}(\mathrm{g})$ is the mass of the residue after complete decomposition, and $\mathrm{m}(\mathrm{g})$ is the mass of anhydrous sulfate at $t(\mathrm{~s})$ during decomposition.

The rate constant $k$ in Eq. 1 follows an Arrhenius expression:

$k=A \cdot \exp \left(-\frac{E}{R T}\right)$ 
where $A\left(\mathrm{~s}^{-1}\right)$ is the pre-exponential factor, $E(\mathrm{~kJ} / \mathrm{mol})$ the activation energy, $R(\mathrm{~kJ} / \mathrm{mol} / \mathrm{K})$ the gas constant, and $T(\mathrm{~K})$ the temperature of the particle.

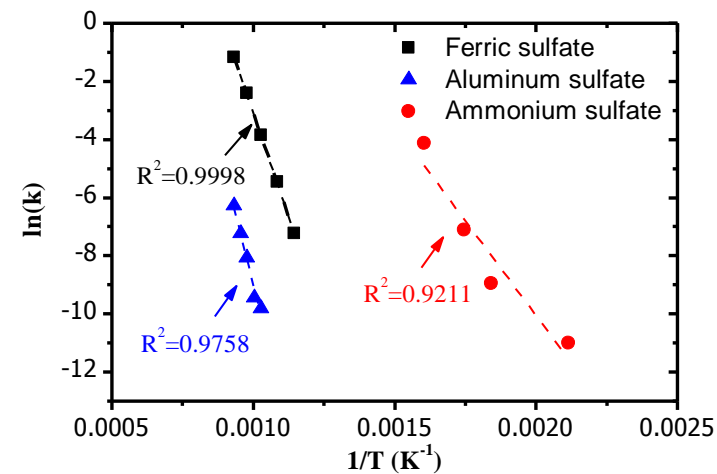

Figure 3: Correlation between $\ln (\mathrm{k})$ and $1 / \mathrm{T}$ during the decomposition of different sulfate in the TGA experiments under isothermal conditions.

The activation energy $(E)$ and the pre-exponential factor $(A)$ in Eq. 3 are derived from the TGA experiments. As shown in Figure 3, during the isothermal periods of the TGA experiments, a high linearity is generally seen between $\ln (\mathrm{k})$ and $1 / \mathrm{T}$, indicating that $\mathrm{Eq}$. 3 can satisfactorily describe the decomposition of the sulfates. Besides, it is also shown that the decomposition rate of sulfates studied in this work generally follows an order of ammonium sulfate>ferric sulfate>aluminum sulfate. The activation energy $(E)$ and the preexponential factor $(A)$ derived from Figure 3 for different sulfates are given in Table II.

Table II: Activation energy and pre-exponential factor derived from Figure 2.

\begin{tabular}{ccc}
\hline & $\mathrm{E} / \mathrm{R}(\mathrm{K})$ & $\mathrm{A}\left(\mathrm{s}^{-1}\right)$ \\
\hline Ammonium sulfate & 13042 & $9.15 \mathrm{E}+06$ \\
Ferric sulfate & 28480 & $1.08 \mathrm{E}+11$ \\
Aluminum sulfate & 38782 & $8.70 \mathrm{E}+12$
\end{tabular}

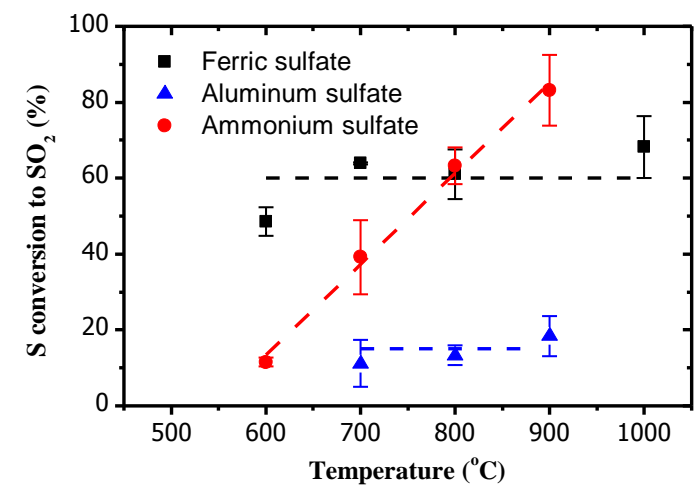

Figure 4: Yields of $\mathrm{SO}_{2}(\%)$ during decomposition of sulfate under different temperatures, the remaining sulfur is assumed to be released as $\mathrm{SO}_{3}$. The dash lines show the yields of $\mathrm{SO}_{2}$ used in the simulation.

Figure 4 shows the results from the laboratory-scale tube reactor experiments. For ferric sulfate, it can be seen that approximately $60 \%$ of the sulfur in ferric sulfate is released as $\mathrm{SO}_{2}$ in the temperature range of $700-1000^{\circ} \mathrm{C}$. Since the decomposition of ferric sulfate in a furnace primarily occurs at temperatures above $700^{\circ} \mathrm{C}$, it is reasonable to assume for modeling purposes that $60 \%$ of the sulfur from ferric sulfate decomposition is released as $\mathrm{SO}_{2}$, whereas the remaining $40 \%$ is released as $\mathrm{SO}_{3}$. This leads to the following equation for ferric sulfate decomposition:

$$
\mathrm{Fe}_{2}\left(\mathrm{SO}_{4}\right)_{3} \rightarrow \mathrm{Fe}_{2} \mathrm{O}_{3}+1.2 \mathrm{SO}_{3}+1.8 \mathrm{SO}_{2}+0.9 \mathrm{O}_{2}
$$

For aluminum sulfate, the yields of $\mathrm{SO}_{2}$ are much smaller than that of ferric sulfate, and it is not significantly influenced by decomposition temperature. Therefore, in the modeling, we assume that $15 \%$ of the sulfur of aluminum sulfate is released as $\mathrm{SO}_{2}$ and the remaining $85 \%$ is released as $\mathrm{SO}_{3}$. This leads to the following equation for aluminum sulfate decomposition:

$$
\mathrm{Al}_{2}\left(\mathrm{SO}_{4}\right)_{3} \rightarrow \mathrm{Al}_{2} \mathrm{O}_{3}+2.55 \mathrm{SO}_{3}+0.45 \mathrm{SO}_{2}+0.225 \mathrm{O}_{2}
$$

For the decomposition of ammonium sulfate, the yields of $\mathrm{SO}_{2}$ increase almost linearly with increasing temperatures (see Figure 4). Therefore, in the modeling, a linear correlation shown as in the dash line in Figure 4 is adopted to simulate the yields of $\mathrm{SO}_{2}$ from ammonium sulfate decomposition at different temperatures, and the remaining sulfur is assumed to be released as $\mathrm{SO}_{3}$. The global decomposition reaction for ammonium sulfate can be written as:

$$
\begin{aligned}
& \left(\mathrm{NH}_{4}\right)_{2} \mathrm{SO}_{4} \rightarrow 2 \mathrm{NH}_{3}+\mathrm{H}_{2} \mathrm{O}+(1-x) \mathrm{SO}_{3} \\
& +x \mathrm{SO}_{2}+\frac{x}{2} \mathrm{O}_{2}
\end{aligned}
$$

where $x$ is the $\mathrm{S}$ conversion to $\mathrm{SO}_{2}$ shown in Figure 4, which is dependent on the decomposition temperature of ammonium sulfate.

\subsection{Detailed chemical kinetic model}

Detailed chemical kinetic model is applied to describe the gas-phase reactions of the potassium, chlorine and sulfur species. The gas phase kinetic model used in this study was based on the reaction mechanism proposed by Hindiyarti et al [12], with updated the thermodynamic properties of the species $\mathrm{KO}_{2}$.

\subsection{Condensation of sulfate}

For homogeneous and heterogeneous condensation of potassium sulfate, a first order reaction as used by $\mathrm{Li}$ et al. [13] is chosen to describe the processes:

$$
\mathrm{K}_{2} \mathrm{SO}_{4}(\mathrm{~g}) \longrightarrow \mathrm{K}_{2} \mathrm{SO}_{4}(\mathrm{~s})
$$

The rate constant for the reaction above, which represents the condensation rate predicted from aerosol theory [16], is:

$$
k_{\text {condensation }}=1 \times 10^{-61} \exp (150000 / T)
$$

\subsection{Simulation of the BFB reactor}

In order to simulate the BFB experiments, the region from the sulfate injection location to the impactor sampling location (see Figure 2) was simulated as an ideal plug flow reactor. The simulation was carried out with CHEMKIN 4.1.1, using the plug-flow reactor model. The temperature profile used in the simulation was predefined based on the profile shown in Figure 2.

The amount and composition of the inlet flue gas were estimated based on the experiment without additive injection. The flue gas was assumed to contain only $\mathrm{N}_{2}$, $\mathrm{O}_{2}, \mathrm{CO}_{2}, \mathrm{H}_{2} \mathrm{O}, \mathrm{SO}_{2}, \mathrm{HCl}$ and $\mathrm{KCl}$. The concentrations of $\mathrm{N}_{2}, \mathrm{O}_{2}, \mathrm{CO}_{2}$ and $\mathrm{H}_{2} \mathrm{O}$ were obtained by assuming that the fuel was fully converted in the reactor. The concentration of $\mathrm{KCl}$ was derived based on the amount of $\mathrm{Cl}$ in the 
aerosols collected during the experiment without additive injection. Although the $\mathrm{Cl}$ collected in the aerosols contained both $\mathrm{KCl}$ and $\mathrm{NaCl}$, in the simulation we assumed that the $\mathrm{Cl}$ found in the aerosols was only comprised of $\mathrm{KCl}$. This assumption is believed to be reasonable since the molar ratio of $\mathrm{K} / \mathrm{Cl}$ found in the aerosols was about 0.9 , suggesting that $\mathrm{KCl}$ was dominated over $\mathrm{NaCl}$. Besides, the sulfation rate of $\mathrm{NaCl}$ would be similar to that of $\mathrm{KCl}$ under boiler conditions. The $\mathrm{HCl}$ concentration in the flue gas was calculated by performing mass balance calculation on $\mathrm{Cl}$, based on the amount of input fuel- $\mathrm{Cl}$ and the $\mathrm{Cl}$ collected as aerosols. Similarly, the $\mathrm{SO}_{2}$ concentration was obtained from the mass balance calculation of $\mathrm{S}$, according to the input fuel-S and the $\mathrm{S}$ collected as aerosols.

For the experiments with additive injection, a pseudo species, $\mathrm{SO}_{3}{ }^{*}$, which produces $\mathrm{SO}_{2}, \mathrm{SO}_{3}$ and $\mathrm{O}_{2}$ upon decomposition (other gas/solid residues such as $\mathrm{NH}_{3}$, $\mathrm{Fe}_{2} \mathrm{O}_{3}$ and $\mathrm{Al}_{2} \mathrm{O}_{3}$ were not considered in the simulation), was defined to simulate the additive in CHEMKIN. The kinetic parameters for suflate decomposition were based on Table II, and the product distribution was defined based on Eq. 4-6.

From the simulation results, the mass flow of $\mathrm{Cl}$ as aerosols was obtained by assuming that that all of the $\mathrm{KCl}$ and $\mathrm{K}_{2} \mathrm{Cl}_{2}$ found at the outlet of the reactor (i.e. the aerosol sampling location) were collected as aerosols.

\subsection{Simulation for sulfate comparison}

For comparing the effectiveness of the different sulfates and $\mathrm{SO}_{3}$, simulation was carried out by using a temperature profile shown in Figure 5, which was estimated based on the cooling rate of the BFB reactor. The simulation was conducted with different sulfate additive and different additive injection temperature, as illustrated in Figure 5. The flue gas composition used in the simulation was the same as that used for simulating the BFB experiments, and the molar ratio of $\mathrm{S}_{\text {additive }} / \mathrm{Cl}_{\text {fuel }}$ was kept at 0.5 .

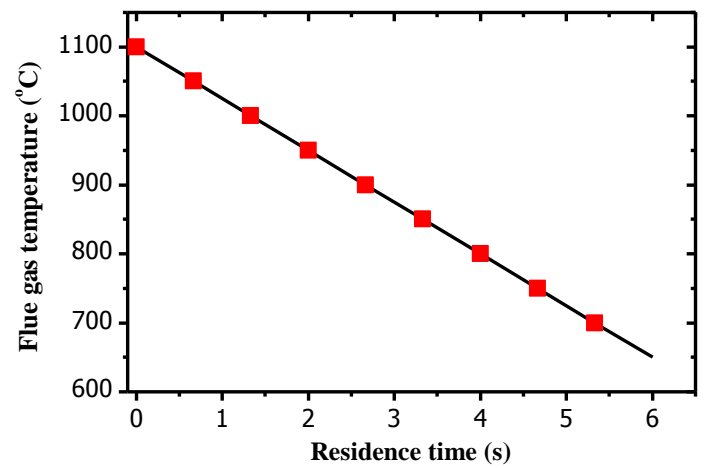

Figure 5: Temperature profile used for comparing the effectiveness of different sulfate and $\mathrm{SO}_{3}$. The solid symbols denote the different additive injection temperature/position used in the simulation.

\section{RESULTS AND DISCUSSION}

\subsection{Ammonium sulfate addition in the BFB reactor}

Figure 6 compares the experimental and simulated mass flow of $\mathrm{Cl}\left(\mathrm{mg} / \mathrm{Nm}^{3}\right)$ in the aerosols during ammonium sulfate addition in the BFB reactor. It can be seen that the model generally captures the experimental results well. The mass flow of $\mathrm{Cl}$ in the aerosols is slightly under-predicted by the model, implying a slight over-prediction of the effectiveness of ammonium sulfate addition on $\mathrm{KCl}$ sulfation. This is mostly like related to an over-estimation of the release of $\mathrm{SO}_{3}$ from ammonium sulfate decomposition, which may be induced by the relative large experimental errors shown in Figure 4.

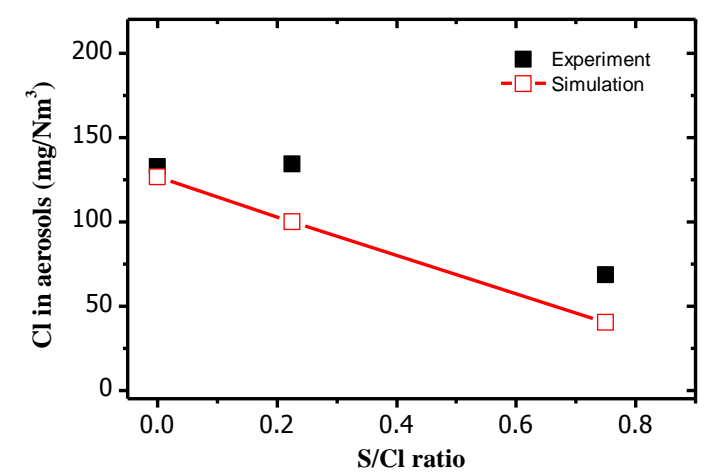

Figure 6: Comparison of the experimental and simulated mass flow of $\mathrm{Cl}\left(\mathrm{mg} / \mathrm{Nm}^{3}\right)$ in the aerosols during ammonium sulfate addtion under different molar ratios of $\mathrm{S}_{\text {additive }} / \mathrm{Cl}_{\text {fuel }}$.

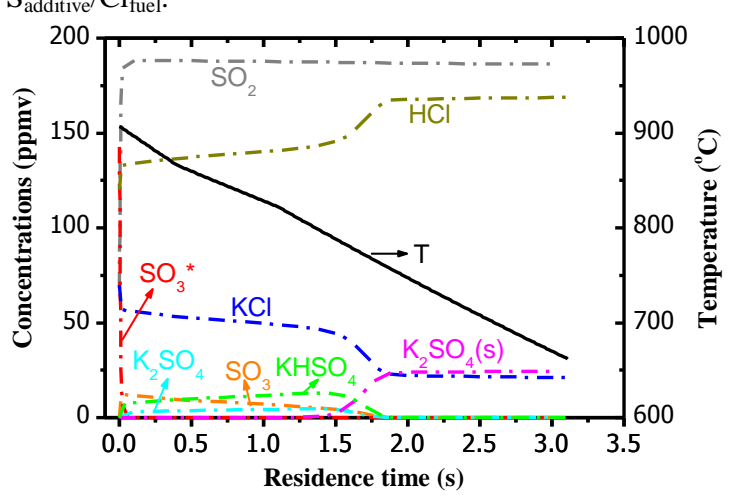

Figure 7: Concentration profiles of the major $\mathrm{S}$ and $\mathrm{Cl}$ species during the simulation of ammonium sulfate addition under a $\mathrm{S}_{\text {additive }} / \mathrm{Cl}_{\text {fuel }}$ ratio of 0.75 .

The distribution of the $\mathrm{S}$ and $\mathrm{Cl}$ species in the simulation zone during ammonium sulfate addition $\left(S_{\text {additive }} / \mathrm{Cl}_{\text {fuel }}=0.75\right)$ is shown in Figure 7. It is seen that under the conditions of the $\mathrm{BFB}$ boiler, the decomposition of ammonium sulfate (denoted as $\mathrm{SO}_{3}{ }^{*}$ ) is completed almost instantaneously $\left(\begin{array}{rll}\sim 0 & \mathrm{~ms}\end{array}\right)$ after injection, forming both $\mathrm{SO}_{2}$ and $\mathrm{SO}_{3}$. The concentration of $\mathrm{SO}_{2}$ becomes constant when the ammonium sulfate is completely decomposed, implying a negligible further conversion of $\mathrm{SO}_{3}$ to $\mathrm{SO}_{2}$. In the residence time of $0-1.5 \mathrm{~s}$, the sulfation of $\mathrm{KCl}$ appears to be thermodynamically constrained, reflected both by the small amount of $\mathrm{K}_{2} \mathrm{SO}_{4}$ formed, and the simultaneous presence of the reactive $\mathrm{SO}_{3}, \mathrm{KHSO}_{4}$ and $\mathrm{KCl}$. In the residence time of about 1.5$2 \mathrm{~s}$, a rapid conversion of $\mathrm{KCl}$ is observed, which is accompanied by the formation of a considerable amount $\mathrm{K}_{2} \mathrm{SO}_{4}$ (s). This is mainly due to the occurrence of homogeneous and heterogeneous condensation of $\mathrm{K}_{2} \mathrm{SO}_{4}$ in the temperature range of $790-750{ }^{\circ} \mathrm{C}$, which removes the gaseous $\mathrm{K}_{2} \mathrm{SO}_{4}$ and promotes the following reactions of $\mathrm{SO}_{3}, \mathrm{KHSO}_{4}$ and $\mathrm{KCl}$ [11]:

$$
\begin{gathered}
\mathrm{KCl}+\mathrm{SO}_{3}(+\mathrm{M})=\left(\mathrm{KO}_{2}\right) \mathrm{S}(\mathrm{O}) \mathrm{Cl}(+\mathrm{M}) \\
\left(\mathrm{KO}_{2}\right) \mathrm{S}(\mathrm{O}) \mathrm{Cl}+\mathrm{H}_{2} \mathrm{O}=\mathrm{KHSO}_{4}+\mathrm{HCl}
\end{gathered}
$$




\subsection{Ferric sulfate addition in the BFB reactor}

A comparison of the experimental and simulated mass flow of $\mathrm{Cl}\left(\mathrm{mg} / \mathrm{Nm}^{3}\right)$ in the aerosols during ferric sulfate addition in the BFB reactor is shown in Figure 8. The simulation results are in good agreement with the experimental results. Both the experimental and simulation results indicate a rather complete sulfation of $\mathrm{KCl}$ under a $\mathrm{S}_{\text {additive }} / \mathrm{Cl}_{\text {fuel }}$ ratio of 0.75 .

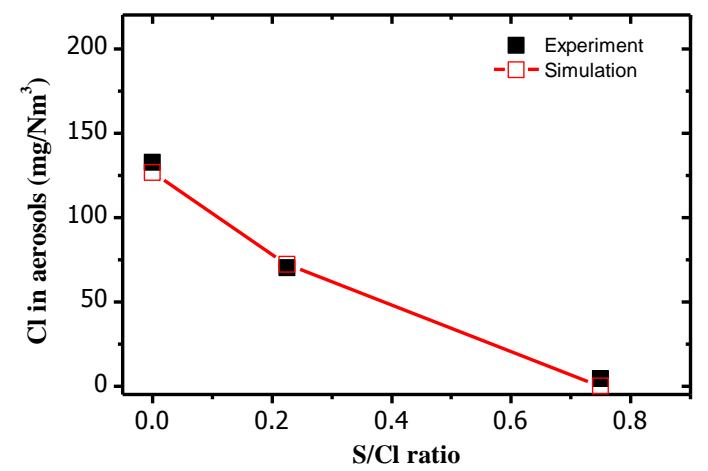

Figure 8: Comparison of the experimental and simulated mass flow of $\mathrm{Cl}\left(\mathrm{mg} / \mathrm{Nm}^{3}\right)$ in the aerosols during ferric sulfate addtion under different molar ratios of $\mathrm{S}_{\text {additive }} / \mathrm{Cl}_{\text {fuel. }}$

The distribution of the $\mathrm{S}$ and $\mathrm{Cl}$ species from the simulation of ferric sulfate is shown in Figure 9. It can be seen that the decomposition of ferric sulfate (denoted as $\left.\mathrm{SO}_{3}{ }^{*}\right)$ is much slower than that of ammonium sulfate. Approximately $15 \%$ of the ferric sulfate remains unconverted at the outlet of the reactor. However, due to the high $\mathrm{S}_{\text {additive }} / \mathrm{Cl}_{\text {fuel }}$ molar ratio (0.75) and the significant release of $\mathrm{SO}_{3}$ from ferric sulfate decomposition, the $\mathrm{KCl}$ in the flue gas is still fully converted to $\mathrm{K}_{2} \mathrm{SO}_{4}$. The conversion of $\mathrm{KCl}$ takes place primarily in the temperature range of $790-750^{\circ} \mathrm{C}$, which is similar to that of ammonium sulfate addition.

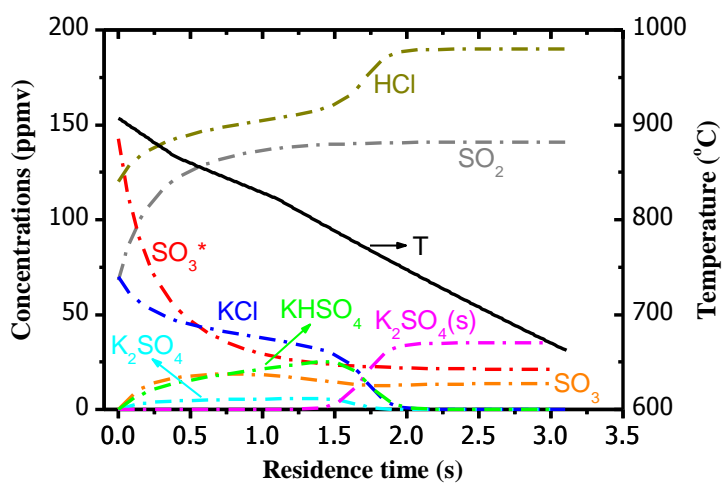

Figure 9: Concentration profiles of the major $\mathrm{S}$ and $\mathrm{Cl}$ species during the simulation of ferric sulfate addition under a $\mathrm{S}_{\text {additive }} / \mathrm{Cl}_{\text {fuel }}$ ratio of 0.75 .

\subsection{Aluminum sulfate addition in the BFB reactor}

Figure 10 presents a comparison of the experimental and simulated mass flow of $\mathrm{Cl}\left(\mathrm{mg} / \mathrm{Nm}^{3}\right)$ in the aerosols during aluminum sulfate addition in the BFB reactor. It appears that the model under-predicts significantly the effect of aluminum sulfate addition, resulting in a much higher mass flow of $\mathrm{Cl}$ in the aerosols than that obtained experimentally. According to the simulation results, only

less than $2 \%$ of the aluminum sulfate is decomposed under the conditions of the BFB reactor, which leads to a very low sulfation degree of the $\mathrm{KCl}$ in the flue gas. However, if the decomposition rate of aluminum sulfate is increased by 100 times, a reasonable good agreement is achieved between the experimental and simulation results (see the dotted line in Figure 10). Therefore, it is most likely that the decomposition rate of aluminum sulfate is under predicted. Compared to the BFB experiments where the aluminum sulfate is injected as liquid spray and is probably dried to nano-size particles before decomposition [9], the particle size of the aluminum sulfate used in the fast-heating rate TGA experiments is much larger. The difference in particle size may result in slower decomposition rate in the fast-heating rate TGA experiments. However, further investigations are needed in order to fully understand the decomposition behavior of aluminum sulfate under boiler conditions, which is outside the scope of this preliminary study.

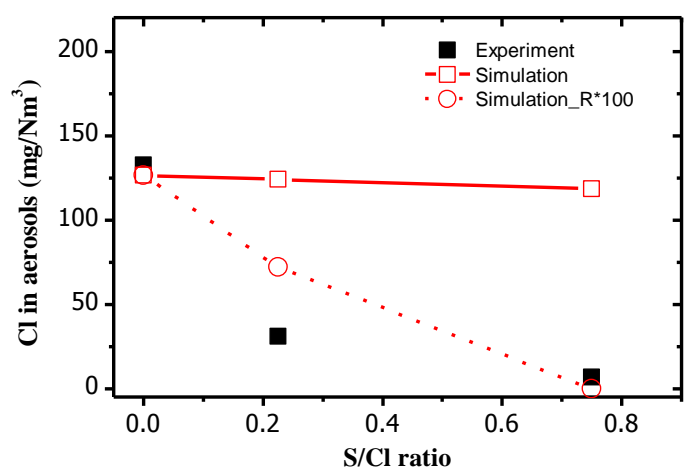

Figure 10: Comparison of the experimental and simulated mass flow of $\mathrm{Cl}\left(\mathrm{mg} / \mathrm{Nm}^{3}\right)$ in the aerosols during aluminum sulfate addtion under different molar ratios of $\mathrm{S}_{\text {additive }} / \mathrm{Cl}_{\text {fuel. }}$ The dotted line shows the simulation results based on a decomposition rate 100 times higher than that estimated from the TGA experiments.

\subsection{Comparison of the effectiveness of sulfate}

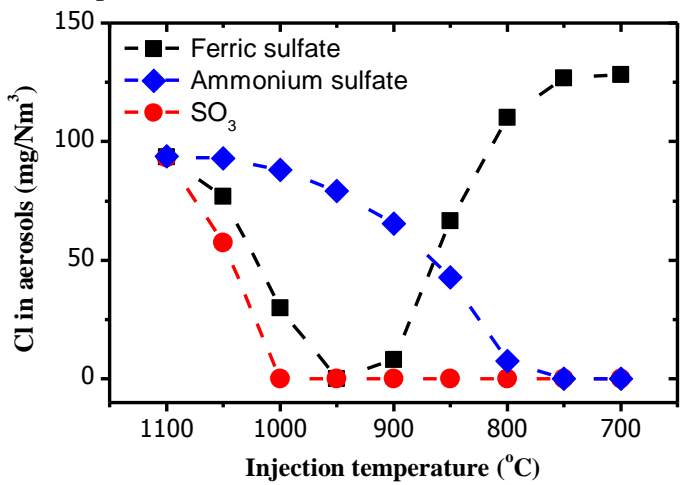

Figure 11: Comparison of the simulated effectiveness of ferric sulfate, ammonium sulfate and $\mathrm{SO}_{3}$ under different injection temperatures according to the profile shown in Figure 5. The $\mathrm{S}_{\text {additive }} / \mathrm{Cl}_{\text {fuel }}$ molar ratio was kept at 0.5.

Figure 11 shows a comparison of the effectiveness of ferric sulfate, ammonium sulfate and $\mathrm{SO}_{3}$ under different injection temperature conditions based on the temperature profile in Figure 5. The results of aluminum sulfate are not presented due to the significant difference between the simulation and experimental results.

It is seen from Figure 11 that the highest 
effectiveness for ferric sulfate addition is achieved when it is injected at around $900-950^{\circ} \mathrm{C}$, resulting in an almost complete destruction of the $\mathrm{KCl}$ in the flue gas. When the injection temperature is increased $\left(\right.$ e.g. $1100^{\circ} \mathrm{C}$ ), the effectiveness of ferric sulfate is decreased due to a more pronounced dissociate of $\mathrm{SO}_{3}$ to $\mathrm{SO}_{2}$ at higher temperatures. However, when the injection temperature is decreased (e.g. $800^{\circ} \mathrm{C}$ ), only a small fraction of ferric sulfate can be decomposed under the residence time conditions of Figure 5, which also limits the effectivness significantly.

The effectivness of ammonium sulfate appears to increase with decreasing injection temperature. This is mainly because that more $\mathrm{SO}_{3}$ is released when the decompostiion of ammonium sulfate takes place at lower temperatures. Under a $\mathrm{S}_{\text {additive }} / \mathrm{Cl}_{\text {fuel }}$ molar ratio of 0.5 , the $\mathrm{KCl}$ is almost totally sulfated when the ammonium sulfate is injected between $800-700^{\circ} \mathrm{C}$. The high effectinvess of ammonium sulfate in this temprature range is mainly related to its fast decomposition rate and the significant release of $\mathrm{SO}_{3}$ (see Figure 4).

The simulated effectiveness of pure $\mathrm{SO}_{3}$ injection is also shown in Figure 11. It is seen that at high injection temperatures (e.g. $1100^{\circ} \mathrm{C}$ ), the effectiveness of $\mathrm{SO}_{3}$ is similar to that of ammonium sulfate and ferric sulfate, due to the rapid dissociation rate of $\mathrm{SO}_{3}$. However, when injected below $1000^{\circ} \mathrm{C}$, a complete sulfation of the $\mathrm{KCl}$ can be achieved under the simulation conditions. This is partly related to the large $\mathrm{S}_{\text {additive }} / \mathrm{Cl}_{\text {fuel }}$ molar ratio (0.5) used in the simulation, which greatly excess the stoichiometric ratio $\left(\mathrm{S}_{\text {additive }} / \mathrm{Cl}_{\text {fuel }}=0.19\right)$ calculated based on the amount of $\mathrm{KCl}$ found in the flue gas.

\section{CONCLUSION}

The results of the present study showed that the yields of $\mathrm{SO}_{3}$ from ferric sulfate and aluminum sulfate decomposition was almost independent of the decomposition temperature (up to $900^{\circ} \mathrm{C}$ ), with ferric sulfate constantly producing about $40 \% \quad \mathrm{SO}_{3}$ and aluminum sulfate generating about $85 \% \quad \mathrm{SO}_{3}$. For ammonium sulfate, the yields of $\mathrm{SO}_{3}$ decreased with increasing decomposition temperature. The models developed for $\mathrm{KCl}$ sulfation by ferric sulfate and ammonium sulfate addition captured the experimental results obtained in a bubbling fluidized bed (BFB) reactor well. However, the model for aluminum sulfate addition predicted a very low sulfation degree of $\mathrm{KCl}$, which conflicted significantly with the high effectiveness of aluminum sulfate observed in the BFB experiments. This discrepancy is most likely related to an under-estimation of the decomposition rate of aluminum sulfate, which requires further investigations. Comparison of the effectiveness of ammonium sulfate and ferric sulfate through simulation suggested that under the boiler conditions similar to the present study, the desirable temperature for the injection of ferric sulfate was around $950-900^{\circ} \mathrm{C}$, whereas for ammonium sulfate the preferable injection temperature was below $800^{\circ} \mathrm{C}$.

\section{ACKNOWLEDGEMENTS}

The Funding from EU contract 23946 "Demonstration of a 16 MW high energy efficient corn stover biomass power plant" is gratefully acknowledged. The funding from TEKES and the support from Metso Power OY to the contribution of VTT is gratefully acknowledged.

\section{REFERENCES}

[1] Nielsen HP, Frandsen FJ, Dam-Johansen K, Baxter LL. The implications of chlorine-associated corrosion on the operation of biomass-fired boilers. Prog Energy Combust Sci 2000;26:283-98.

[2] Bashir MS, Jensen PA, Frandsen FJ, Wedel S, DamJohansen K, Wadenback J, Pedersen ST. Ash transformation and deposit build-up during biomass suspeinson and grate-firing: Full-scale experimental studies. Fuel Process Technol 2012;97:93-106.

[3] Frandsen FJ. Utilizing biomass and waste for power production- $\mathrm{a}$ decade of contributing to the understanding, interpretation and analysis of deposits and corrosion products. Fuel 2005;84:1277-94

[4] Hupa M. Ash related issues in fluidized bed combustion of biomasses-recent research highlights. Energy Fuels 2012;26:4-14.

[5] Åmand LE, Leckner B, Eskilsson D, Tullin C. Ash deposition on heat transfer tubes during combustion of demolition wood. Energy Fuels 2006;20:1001-7.

[6] Aho M, Paakkinen K, Taipale R. Quality of deposits during grate combustion of corn stover and wood chip blends. Fuel 2013;104:476-87.

[7] Wu H, Glarborg P, Frandsen FJ, Dam-Johansen K, Jensen PA. Dust-firing of straw and additives: ash chemistry and deposition behavior. Energy Fuels 2011;25:2862-73.

[8] Aho M, Paakkinen K, Taipale R. Destruction of alkali chlorides using sulphur and ferric sulphate during grate combustion of corn stover and wood chip blends. Fuel 2013;103:562-9.

[9] Aho M, Vainikka P, Taipale R, Yrjas P. Effective new chemicals to prevent corrosion due to chlorine in power plant superheaters. Fuel 2008;87:647-54.

[10] Kassman H, Bäfver L, Åmand LE. The importance of $\mathrm{SO}_{2}$ and $\mathrm{SO}_{3}$ for sulphation of gaseous $\mathrm{KCl}-\mathrm{An}$ experimental investigation in a biomass fired CFB boiler. Combust Flame 2010;157:1649-57.

[11] Glarborg P, Marshall P. Mechanism and modeling of the formation of gaseous alkali sulfates. Combust Flame 2005;141:22-39.

[12] Hindiyarti L, Frandsen F, Livbjerg H, Glarborg P, Marshall P. An exploratory study of alkali sulfate aerosol formation during biomass combustion. Fuel 2008;87:1591-600.

[13] Li B, Sun Z, Li Z, Aldén M, Jakobsen JG, Hansen S, Glarborg P. Post-flame gas-phase sulfation of potassium chloride. Combust Flame 2013;160:959-69.

[14] Wu H, Castro M, Jensen PA, Frandsen FJ, Glarborg P, Dam-Johansen K, Røkke M, Lundtorp K. Release and transformation of inorganic elements in combustion of a high-phosphorus fuel. Energy Fuels 2011:2886.

[15] Nielsen AR, Larsen MB, Glarborg P, Dam-Johansen $\mathrm{K}$. High temperature release of $\mathrm{SO} 2$ from calcined cement raw materials. Energy Fuels 2011.

[16] Christensen KA, Livbjerg H. A plug flow model for chemical reactions and aerosol nucleation and growth in an alkali-containing flue gas. Aerosol Sci Tech 2000;33:470-89. 